\title{
An Overview on Short and Long-Term Response Energy Storage Devices for Power Systems Applications
}

\author{
Sérgio Faias ${ }^{1}$, Patrícia Santos ${ }^{1}$, Jorge Sousa ${ }^{1}$, Rui Castro ${ }^{2}$ \\ ${ }^{1}$ Instituto Superior de Engenharia de Lisboa, DEEA/ISEL \\ Rua Conselheiro Emídio Navarro, 1, 1950-062 Lisboa, Portugal \\ Phone: +351218317000, e-mail: sfaias@deea.isel.ipl.pt, psantos@deea.isel.ipl.pt, jsousa@deea.isel.ipl.pt \\ ${ }^{2}$ Instituto Superior Técnico / Technical University of Lisbon, IST/TUL \\ Av. Rovisco Pais, 1049-001 Lisboa, Portugal \\ e-mail: rcastro@ist.utl.pt
}

\begin{abstract}
Energy storage devices provide valuable benefits to improve stability, power quality and reliability of supply. Storage technologies have developed significantly in order to meet the challenges of practical power systems applications.

Energy storage devices can be classified into short and longterm response, depending on their application. Technologies with high power density and with the ability to respond to the requests in short time fractions like flywheels, capacitors or superconducting magnetic coils belong to the so-called shortterm response energy storage devices category. Energy storage devices with the capability to absorb and supply electrical energy for long periods of time like pumping hydro, batteries, compressed air and hydrogen fuel cells are considered in the long-term response category.
\end{abstract}

This paper concentrates on the latest short and long-term energy storage technology developments, performance analysis, and cost considerations.

\section{Keywords}

Energy storage, power systems balancing, energy management, renewable sources integration, voltage stability

\section{Introduction}

Power systems are experiencing significant changes in operational requirements that result from the sector restructure and evolution. Largely interconnected network, distributed and renewable generation lead to more complex and less secure power system operation.

Energy storage appears to be beneficial to utilities since it can decouple the instantaneous balancing between the demand and the supply. Therefore it allows the increased asset utilization, facilitates the penetration of renewable sources and improves the flexibility, reliability and efficiency of the grid [1].

However, the use of energy storage devices has not expanded significantly because of the state of technological developments and the price of energy storage devices which are still costly [2].

Nonetheless, there are several high performance storage technologies available today, or at an advanced state of development, which enables a new range of storage applications. For example, the issues related to the increasing integration of renewable sources in power systems have been one of the main drivers of this development.

Energy storage devices can be classified into two different categories, depending on their application: short-term response energy storage devices and long-term response energy storage devices.

Long-term response energy storage devices for power systems applications can usually absorb and supply electrical energy during minutes or hours and can specially contribute on the energy management, frequency regulation and grid congestion management [3], [4].

Short-term response energy storage devices are usually applied to improve power quality, particularly to maintain the voltage stability in power systems, throughout a contribution during transients (few seconds or minutes) [4].

\section{Objectives and Methodology}

This paper intends to present a survey on energy storage devices for power systems, focusing the distinction between short and long-term response technologies.

An operation description of the available energy storage technologies will be presented followed by some application cases.

The main contribution of this paper comes from the technology comparison with special attention given to characteristics like power and energy range, efficiency, life-time and costs.

\section{Long-Term Response Energy Storage Devices}

The so-called long-term response energy storage devices have the capability to supply or absorb electrical energy during hours. Their power systems application is usually 
related with energy management, frequency regulation or grid congestion management [3], [4].

The use of long-term energy storage devices is expected to rise in the next years because the generation availability fluctuations associated to the increasing integration of renewable sources in power systems [1].

Sort of different long-term response energy storage technologies are already available today. A brief description of these main devices is presented below.

\section{A. Pumping hydro}

In pumping hydro storage, a body of water at a relatively high elevation represents a potential or stored energy. During peak hours the water in the upper reservoir is lead through a pipe downhill into a hydroelectric generator and stored in the lower reservoir. Along off-peak periods the water is pumped back up to recharge the upper reservoir and the power plant acts like a load in power system [5], [6].

The pumping hydro system set-up is presented in Fig. 1.

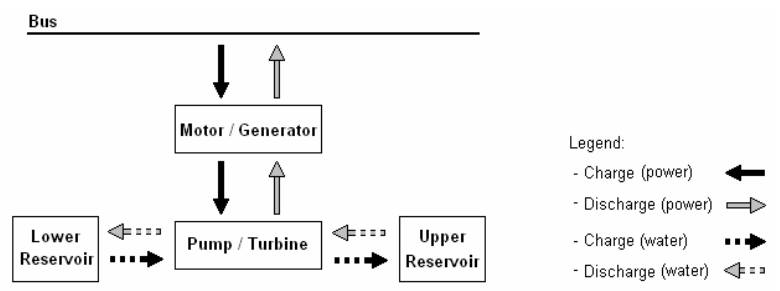

Fig. 1: Pumping hydro system set-up

Pumping hydro energy storage system consists in two large water reservoirs, electric machine (motor/generator) and reversible pump-turbine group or pump and turbine separated. This system can be started-up in few minutes and its autonomy depends on the volume of stored water.

Restrictions to pumping hydro energy storage are related with geographical constraints and weather conditions. In periods of much rain, pumping hydro capacity can be reduced.

In Portugal, at 2006, the pumping-hydro installed capacity was 615 MW. This capacity had been used, during the last years, to store at the imported off-peak power from Spain.

\section{B. Batteries}

Batteries store energy in electrochemical form creating electrically charged ions. When the battery charges, a direct current is converted in chemical energy, when discharges, the chemical energy is converted back into a flow of electrons in direct current form [7]. The connection of the system to the grid, as presented in Fig. 2 , implies the use of power electronic converters in order to rectify the alternate current and to invert the direct current.

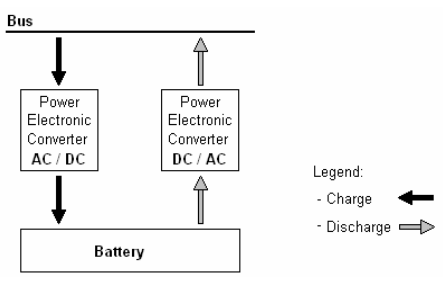

Fig. 2: Working scheme of battery device

Batteries are the most popular energy storage devices. However, the term battery comprises a sort of several technologies applying different operation principals and materials.

Along this paper the distinction between two important battery concepts, electrochemical and redox flow, is emphasized.

\section{1) Electrochemical}

Electrochemical batteries use electrodes both as part of the electron transfer process and store the products or reactants via electrode solid-state reactions [3].

There are a number of battery technologies under consideration for energy storage, where the main are:

- Lead acid

- Nickel cadmium

- Sodium sulphur

- Lithium ion

- Sodium nickel chloride

\section{2) Redox Flow}

Redox flow batteries are storage devices that convert electrical energy into chemical potential energy by charging two liquid electrolyte solutions and subsequently releasing the stored energy on discharge [8].

The name redox flow battery is based on the redox reaction between the two electrolytes in the system. These reactions include all chemical processes in which atoms have their oxidation number changed. In a redox flow cell the two electrolytes are separated by a semipermeable membrane. This membrane permits ion flow, but prevents mixing of the liquids. Electrical contact is made through inert conductors in the liquids. As the ions flow across the membrane, an electrical current is induced in the conductors. [9]

Over the past few years three types of flow batteries were developed up to the stage of commercialization and demonstration. These types are vanadium cells (Vanadium Redox Batteries, VRB), Polysulphide Bromide Batteries (PSB) and zinc bromine ( $\mathrm{ZnBr}$ ). Each type has its own specifications and is developed for a specific application. [9]

This technology is suitable for energy storage application in the 5-500 MW range, operating in time fractions from 1 second to 12 hours. [3] 
The first system based on Polysulphide Bromide Battery started to be built in Little Barford in the United Kingdom, with a combined-cycle power plant with the aim of load leveling. It was envisaged that came into operation in 2003, though some delays have led this unit does not come into operation and in 2004 the Regenesys stopped development of fuel cell type PSB. It was planned to this central a capacity of $120 \mathrm{MWh}$, with a peak power of $15 \mathrm{MW}$ and more than 15 years of useful life, as well as efficiency between 60 and 65\% with response time of less than $100 \mathrm{~ms}$.

\section{Compressed air}

In compressed air energy storage, off-peak hours power is taken from the grid and used to pump and compress air into a sealed underground cavern to a high pressure. The pressurized air is then kept underground for peak periods use. When needed, this high pressure air can drive turbines as the air in the cavern is released and slowly heated.

More often, the compressed air is mixed with natural gas and burnt together, in a conventional gas turbine. This method is actually more efficient as the compressed air will lose less energy.

The set-up of a compressed air system is presented in Fig. 3.
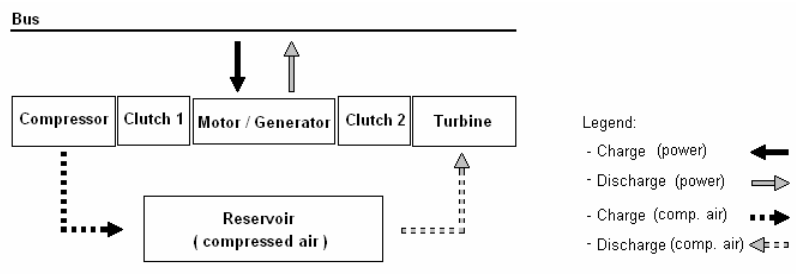

Fig. 3: Example of a compressed air system set-up

There are components required by a basic CAES installation, such as the motor/generator which employs clutches to provide alternate engagement to the compressor or turbine trains; the air compressor which may require two or more stages, intercoolers and aftercoolers to achieve economy of compression, and reduce the moisture content; the recuperator, turbine train, high and low pressure turbines and auxiliary equipment consisting of fuel storage and handling. [10]

Three air reservoir types are generally considered: naturally occurring aquifers (such as those used for natural gas storage), solution-mined salt caverns, and mechanically formed reservoirs in rock formations. Mainly implementation constraints are related with reservoirs achievement [2].

The world's first CAES plant, the Huntorf plant, located in North Germany, was commissioned in 1978. This system has a total capacity of 290 MW, with storage capacity of approximately $600 \mathrm{MWh}$. The compressed air is used to actuate the turbines used for a nuclear power plant that is next. To be able to use this storage capacity up to two caves of salt-yolk with $500,000 \mathrm{~m}^{3}$ and $1,100,000 \mathrm{~m}^{3}$, store the air at a maximum pressure of 100 atm. [11]

\section{Hydrogen fuel cell}

A fuel cell is an energy conversion device that is closely related to a battery. Both are electrochemical devices for the conversion of chemical to electrical energy. In a battery the chemical energy is stored internally, whereas in a fuel cell the chemical energy (fuel and oxidant) is supplied externally and can be continuously replenished. [12]

The overall reaction in a fuel cell is the spontaneous reaction of hydrogen and oxygen to produce electricity in water. During the operation of a fuel cell, hydrogen is ionized into protons and electrons at the anode, the hydrogen ions are transported through the electrolyte to the cathode by an external circuit (load). At the cathode, oxygen combines with the hydrogen ions and electrons to produce water.

The hydrogen fuel cell system can be reversible, allowing electric power consumption for the production of hydrogen and that hydrogen can be stored for later use in the fuel cell. [2], [13]

The working scheme of a hydrogen fuel cell system is presented in Fig. 4.

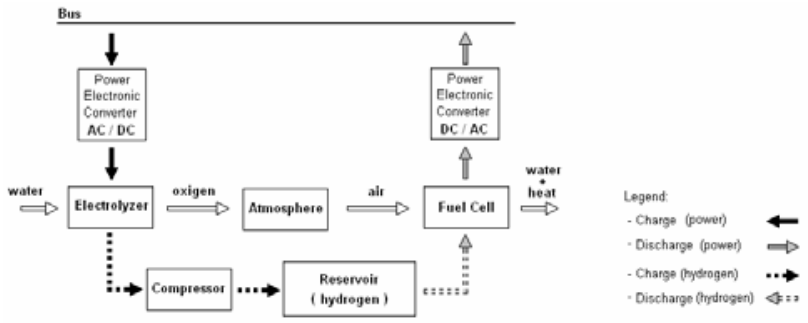

Fig. 4: Hydrogen fuel cell system working scheme

Today, several fuel cell types are available, and can be characterized by the electrolyte used as well as its operational temperature. Hydrogen is the fuel required for all low and medium temperature fuel cells, i.e., the alkaline fuel cell (AFC), the proton exchange membrane fuel cell (PEMFC) and the phosphoric acid fuel cell (PAFC). High-temperature fuel cells, the molten carbonate fuel cell (MCFC) and the solid oxide fuel cell (SOFC), will run on hydrogen, carbon monoxide and some hydrocarbons. [14]

Hydrogen volatility and its atoms reduced dimension put the hydrogen storage reservoir as the critical element in this device. Last research place Metallic Hydrates as one of most efficient [13], [15].

At moment, hydrogen fuel cell systems become one of the most referred storage technologies to set up renewable energy integration issue. Price and overall efficiency are its main constraints. 


\section{Short-Term Response Energy Storage Devices}

Short-term response energy storage devices should be used to aid power systems during the transient period after a system disturbance, such as line switching, load changes and fault clearance. Their application prevents collapse of power systems due to loss of synchronism or voltage instability, improving its reliability and quality.

Short-term response energy storage devices use is getting common in power systems with important renewable energy penetration like wind and weak interconnections or in islands, avoiding temporary faults and contributing to the provision of important system services such as momentary reserves and short-circuit capacity. [16]

The main short-term energy storage devices and their operation are presented below.

\section{A. Flywheels}

Flywheels store kinetic energy in a rotating mass. Such equipments have typically been used as short-term energy storage devices for propulsion applications such as powering train engines and road vehicles, and in centrifuges. In these applications, the flywheel smoothes the power load during deceleration by dynamic braking action and then provides a boost during acceleration [5]. Fig. 5 presents the operating scheme of the flywheel system.

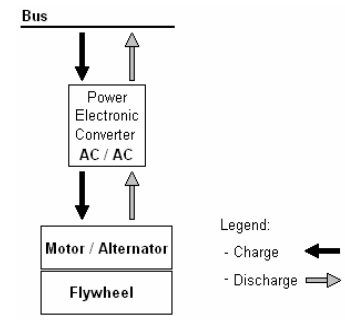

Fig. 5: Flywheel device operating scheme

The energy storage module is a kinetic-energy-based storage device that contains a flywheel rotor assembly and a motor / generator. This module consists of a multicomponent design consisting in a flywheel, shaft and bearing systems, an electric machine, a sealed, selfcontained and maintenance free vacuum system, to maintain low pressure for the service life of the unit, as well as a steel, fully-welded, pressure vessel designed to maintain low pressure. It is the structural support for the flywheel rotor assembly and bearing system. No rubber or metal seals are used at assembly interfaces to avoid gas permeation, and to reduce cost. [17]

At moment, in Portugal, there are two systems based on flywheels, implemented in Flores and Graciosa Islands, Azores. Over the past two years, EDA (Azores Electricity Company) worked with PowerCorp to maximize the wind penetration into the power system of these two islands. Thus, in March 2005, EDA and PowerCorp installed a $350 \mathrm{~kW} \mathrm{/} 5 \mathrm{kWh}$ flywheel device at Flores Island, where the generation consists in 2 wind turbines (15\% of installed capacity), 4 diesel generators and 4 hydro-generators, totalizing 4.2 MW. Results obtained, in terms of network stability, encouraged the implementation of a similar system at Graciosa Island. [16]

\section{B. Supercapacitors}

Supercapacitors are the latest innovational devices in the field of electrical energy storage. In comparison with a battery or a traditional capacitor, the supercapacitor allows a much powerful power and energy density [18].

Supercapacitors are electrochemical double layer capacitors that store energy as electric charge between two plates, metal or conductive, separated by a dielectric, when a voltage differential is applied across the plates. As like battery systems, capacitors work in direct current. This fact imposes the use of electronic power systems, as presented in Fig.6. [19]

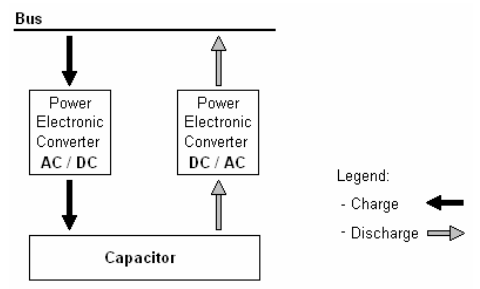

Fig. 6: Working scheme of capacitor device

Supercapacitors find their place in many applications where energy storage is needed, like uninterruptible power supplies, or can help in smoothing strong and short-time power solicitations of weak power networks. Their main advantages are the long cycle life and the short charge/discharge time. [2], [19]

\section{Magnetic Superconducting}

Superconducting magnetic energy storage (SMES) systems convert the ac current from a power system into the dc current flowing in the superconducting coil and store the energy in the form of magnetic field. The stored energy can be released to the ac system when necessary.

The SMES device set-up is presented in Fig. 7.

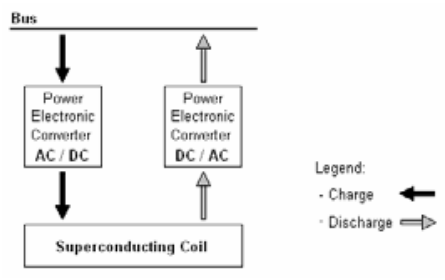

Fig. 7: Set-up of a SMES device

The conductor for carrying the dc current operates at cryogenic temperatures where it is a superconductor and thus has virtually no resistive losses as it produces the 
magnetic field. Consequently, the energy can be stored in a persistent mode, until required. The most important advantage of SMES is that the time delay during charge and discharge is quite short. Power is available almost instantaneously and very high power output can be provided for a brief period of time. [20], [21]

The performances of SMES offer very desirable benefits to power system applications. The first SMES power system application was proposed in 1969, with the objective of charging the superconducting magnet with the surplus generation of the basic load units during offpeak time, and discharge to the ac power system during peak time. In 1981, the first superconducting power-grid application was achieved. A SMES device for power quality and grid stability was located on the $500 \mathrm{kV}$ Pacific Intertie that interconnects California and the Northwest, USA. This application demonstrated the viability of SMES to improve transmission capacity by damping inter-area modal oscillations. Since that time many studies and prototypes have been developed. [22], [23]

\section{Energy Storage Devices Comparison}

Long and short-term response energy storage devices are used with different purposes, as well their characteristics comparison will be presented separately.

A summary of the main long-term response energy storage devices characteristics is presented in table I.

TABLE I - Long-term response energy storage devices characterization [1], [2], [7], [15]

\begin{tabular}{|c|c|c|c|c|}
\hline \multirow{2}{*}{ Characteristics } & \multicolumn{4}{|c|}{ Technology } \\
\cline { 2 - 5 } & $\begin{array}{c}\text { Pumping } \\
\text { hydro }\end{array}$ & Batteries & $\begin{array}{c}\text { Compres. } \\
\text { air }\end{array}$ & $\begin{array}{c}\text { Hyd. fuel } \\
\text { cells }\end{array}$ \\
\hline Power (MW) & $100-3000$ & $<100$ & $100-3000$ & $<50$ \\
\hline Energy (MWh) & $<10000$ & $<500$ & $50-5000$ & --- \\
\hline Charg-disch. effic & $80 \%$ & $50-90 \%$ & $75 \%$ & $20-36 \%$ \\
\hline Life-time (cycles) & 40 years & $10^{3}-10^{4}$ & 30 years & $10^{4}$ hours \\
\hline Price $(€ /$ kWh) & $35-70$ & $70-4000$ & $10-70$ & --- \\
\hline
\end{tabular}

Pumping-hydro and compressed air systems are the best suited for centered large-scale storage, as result of their high power and energy capacity and the geographical implementation limitations.

Batteries and hydrogen fuel cell systems, on the other hand, are more modular and do not present so many physical restrictions to their implementation, being ideal for distributed storage.

Charge-discharge efficiency is one of most important issues for storage devices used in energy management. Hydrogen fuel cell system presents the lowest global efficiency, which results from its elements efficiency, since the hydrogen production till its use in the fuel cell. However, like this is an emergent technology, future efficiency improvements are expected.
Usually, high price and short life-cycle did not allowed a massive use of batteries in power systems, however redox flow batteries introduced a new dynamic in these storage solutions and present an important development potential, specially for the grid integration of variable renewable energies like wind.

Short-term response energy storage devices characterization is presented in table II.

TABLE II - Short-term response energy storage devices characterization [1], [2], [16], [20], [24]

\begin{tabular}{|c|c|c|c|}
\hline \multirow{2}{*}{ Characteristics } & \multicolumn{3}{|c|}{ Technology } \\
\cline { 2 - 4 } & Flywheels & $\begin{array}{c}\text { Super } \\
\text { capacitors }\end{array}$ & SMES \\
\hline Power (MW) & $<10$ & $<10$ & $<100$ \\
\hline Energy (MWh) & $<5$ & $<3$ & $<1000$ \\
\hline Charg-disch. effic & $90 \%$ & $90 \%$ & $95 \%$ \\
\hline Life-time (cycles) & $10^{6}$ & $10^{6}$ & $10^{6}$ \\
\hline Price (€/kW) & $140-350$ & $70-400$ & $200-500$ \\
\hline
\end{tabular}

Flywheels and capacitors, although last developments in their manufacture materials, are well known technologies in opposite to superconducting magnetic devices.

Supercapacitors are the most compact short-term energy storage devices, use the simplest operation apparatus and are virtually maintenance free.

Flywheels present a higher range, in terms of energy storage capacity. They are also cheaper than supercapacitors for high energy capacity. Because mobile mechanical component and to avoid human and material hazardous, flywheels operation requires some special maintenance and safety concerns.

\section{Conclusions and Perspectives}

Energy storage devices provide valuable benefits to improve stability, power quality, and reliability of supply in power systems.

In this regard, this paper presents an overview on energy storage devices for power systems applications in the framework of a broader project that intends to project an energy storage system for facilities based on nondispatchable renewable energies.

From the analysis performed, it is concluded that longterm energy storage devices like pumping-hydro and compressed air systems are the best suited for centered large-scale storage, on the other hand, batteries and hydrogen fuel cell systems space requirements and modularity place them as ideal solution for distributed energy storage.

Moreover, short-term response energy storage devices like supercapacitors are found to be well suited for use in power systems during transient periods that result from a system disturbance such as a line switching. Flywheels, with higher energy storage capacity look like the most 
appropriate to maintain voltage level and frequency, especially in power systems with considerable penetration of renewable energy like wind.

Further developments will focus on the dimensioning and development of an energy storage system for a Portuguese wind farm where short and long-term technologies will be combined.

\section{References}

[1] "Variability of Wind Power and other Renewables: Management Options and Strategies”, International Energy Agency Publications, June 2005

[2] Susan M. Schoenung, James M. Eyer, Joseph J. Iannucci, Susan A. Horgan, "Energy Storage for a Competitive Power Market”, Annual Review of Energy and the Environment, Vol. 21, Issue 1, November 1996

[3] A. Price, S. Bartley, S. Male, G. Cooley, “A Novel Approach to Utility Scale Energy Storage", Power Engineering Journal, Vol. 13, Issue 3, pp 122-129, June 1999

[4] John O. G. Tande, “Grid Integration of Wind Farms”, Wind Energy Vol. 6, No. 3, pp 281-295, September 2003

[5] Electricity Storage Association, <URL: www.electricitystorage.org $>$ (accessed September 2007)

[6] H. Lee Willis, Walter G. Scott, Distributed Power Generation, Planning and Evaluation, Marcel Deker, New York (2000)

[7] G. L. Hunt, “The Great Battery Search”, Spectrum IEEE, Vol. 35, Issue 11, November 1998

[8] C. Ponce de León, A. Frías-Ferrer, J. GonzálezGarcía, D. A. Szánto, F. C. Walsh, "Redox Flow Cells for Energy Conversion”, Journal of Power Sources, Vol. 160, Issue 1, pp 716-732, September 2006

[9] A. Nourai, "Large-Scale Electricity Storage Technologies for Energy Management”, Power Engineering Society Summer Meeting, Vol. 1, pp 310315, July 2002

[10] Edwin Lerch, "Storage of Fluctuating Wind Energy”, Proceedings of EPE 2007 - 12th European Conference on Power Electronics and Applications, Aalborg, September 2007

[11] Fritz Crotogino, K. Mohmeyer, Roland Scharf, "Huntorf CAES: More than 20 Years of Successful Operation”, SMRI Spring 2001 Meeting, Orlando, Florida, USA, April 2001

[12] D. F. Warne, Newnes Electrical Power Engineer's Handbook, $2^{\text {nd }}$ Edition, Elsevier Newnes, Oxford (2005)

[13] K. Agbossou, M. Kolhe, J. Hamelin, T. K. Bose, "Performance of a Stand-Alone Renewable Energy
System Based on Energy Storage as Hydrogen”, IEEE Transactions on Energy Conversion, Vol. 19, No. 3, September 2004

[14] Gregor Hoogers, Fuel Cell Technology Handbook. CRC PRESS, USA (2002)

[15] Joan M. Ogden, "Prospects for Building a Hydrogen Infrastructure” Annual Review of Energy and the Environment, Vol. 24, pp 227-279, 1999

[16] N. Hamsic, A. Schmelter, A. Mohd, E. Ortjohann, E. Schultze, A. Tuckey, J. Zimmermann, "Increasing Renewable Energy Penetration in Isolated Grids Using a Flywheel Energy Storage System", Proceedings of Powereng 2007 - International Conference on Power Engineering, Energy and Electrical Drives, Setúbal, April 2007

[17] Matthew L. Lazarewicz, Alex. Rojas, “Grid Frequency Regulation by Recycling Electrical Energy in Flywheels" IEEE-Power Engineering Society General Meeting. Vol.2, pp. 2038- 2042, June 2004

[18] N.S. Zhai, Y.Y. Yao, D.I. Zhang, D.G. Xu, “Design and Optimization for a Supercapacitor Application System”, International Conference on Power System Technology, pp. 1-4, October 2006

[19] A. Rufer, D. Hotellier, P. Barrade, “A Supercapacitor-Based Energy Storage Substation for Voltage Compensation in Weak Transportation Networks”, IEEE Transactions on Power Delivery, Vol. 19, N0. 2, pp 629-636, April 2004

[20] Toshiyuki Mito, "Development of UPS-SMES as a Protection From Momentary Voltage Drop”, IEEE Transactions on Applied Superconductivity, Vol. 14, N0. 2, pp 721-726, June 2004

[21] X D Xue, K W E Cheng, D. Sutanto, A study of the status and future of superconducting magnetic energy storage in power systems, Institute of Physics Publishing, Superconductor Science and Technology (2006)

[22] C. S. Hsu, W. J. Lee, "Superconducting Magnetic Energy Storage for Power System Applications”, IEEE Transactions on Industrial Applications, Vol. 29, No. 5, pp. 990-996, September/October 1992

[23] W. V. Torre and S. Eckroad, "Improving Power Delivery Through The Application of Superconducting Magnetic Energy Storage (SMES)”, 2001 IEEE Power Engineering Society Winter Meeting Conference, Vols. 1-3, pp. 81-87, 2001

[24] T. Sels, C. Dragu, T. Van Craenenbroeck, R. Belmans, "Overview of new energy storage systems for an improved power quality and load managing on distribution level”, 16th International Conference and Exhibition on Electricity Distribution, Vol.4, pp 5, Amsterdam, June 2001. 